\title{
Physical Elements Transformation on Social Houses at Kinikdog Hamlet Mentawai Islands Regency
}

\author{
Eljihadi Alfin ${ }^{1, *}$ Gregorius Prasetyo Adhitama ${ }^{2}$
}

\author{
${ }^{1}$ Institut Teknologi Bandung, Indonesia \\ ${ }^{2}$ Institut Teknologi Bandung, Indonesia \\ ${ }^{*}$ Corresponding author. Email: alfin.eljihadi@gmail.com
}

\begin{abstract}
In 2008, the people of Matotonan village received assistance in the form of two hundred social housing units from the government. Social house is a term used to describe housing assistance provided by the government based on the Decree of the Minister of Social Affairs of the Republic of Indonesia number 09 of 2012 concerning Empowerment of Remote Indigenous Communities (KAT). Over time, the social houses have encountered the latest advancement according to the people's needs. This research aims to explain how the transformation of the physical elements occurs in the social houses of Kinikdog Hamlet and identify certain factors causing the transformation so that the findings can be used as a recommendation for the next social house constructions. This research uses a qualitative approach and observing physical traces technique. The data are collected using some combined methods, namely non-participant field observations, in-depth interviews, and building measurements for primary data, as well as literature review for the secondary one. The physical elements transformation is measured using a comparative method between the initial and current conditions of the social houses. The physical elements of the social houses have transformed over time, especially in their shape and dimensional aspects. However, the social house orientation remains the same. Meanwhile, the materials, color, and apertures of the social house do not change much, but there are some necessary additions. Culture and technology are the most influencing factors for the social house physical elements transformation.
\end{abstract}

Keywords: Transformation, physical elements, "social houses", Mentawai

\section{INTRODUCTION}

The social house of Kinikdog Hamlet in the Mentawai Islands Regency is one of the social empowerment programs for Remote Indigenous Communities (KAT) in Indonesia. This program is designed and developed to improve KAT's social welfare and is regulated in Presidential Decree number 111/1999 on the Social Welfare of Remote Indigenous Communities (KAT). Currently, Kinikdog Hamlet which is located in Matotonan Village in South Siberut District has received assistance from RS-RTLH twice. The first one was in 2008 in the form of 200 units of social house, and the second one was in 2019 where there were 100 housing units built.

If we observe more deeply, the design of the social house has transformed quite significantly. This is following what was stated in the introduction to the general guidelines for simple and healthy houses and the Decree of the Minister of Housing and Regional Infrastructure Number 403/KPTS/M/2002, "In fact, Simple Houses/Very Simple Houses, after 23 years of occupancy, undergo changes made by the owners, and most of the changes leave only one room." In the introduction, it has been described that the transformations are driven by human nature that always wants and tries to reveal their original identities. However, unlike what was stated by the Decree of the Minister of Housing and Regional Infrastructure, the social houses located in Kinikdog Hamlet have undergone direct changes after the official ones were handed over to the local people. Even some of them have prepared materials to make additions when the social housing is still under 
construction. Another distinguished matter is that the people of Matotonan Village try to always maintain the entire composition of the houses so that the rooms within do not change significantly from the beginning.

Besides, from field observation data, there are still problems in the development of social housing, such as there are still local people who are reluctant to live in social houses that have been built by the government, there has been no evaluation and study of academic designs, and there is no specific design reference in the construction of social houses for KAT. Those are some challenges that must be immediately addressed by stakeholders, because from the data submitted by the Director of KAT (in merdeka.com, 18 October 2017), there are still around 119 thousand of KAT families who will be the target of social settlement stimulant assistance by the government. Therefore, to prepare the construction of social houses, this research is carried out within a case study of the social house of Kinikdog Hamlet, Mentawai Village, Mentawai Islands Regency which aims to answer three research questions, namely: 1) How is the pattern of physical elements transformation?; 2) What are the factors that influence the transformation?; 3) How should the design of the social house be to accommodate the needs of the occupants and be adaptive if it is developed in the future?

\section{METHODS}

This research uses a qualitative approach by observing physical traces. The physical traces are carried out on social houses located in Kinikdok Hamlet, Matotonan Village, South Siberut District, Siberut Island, Mentawai Islands Regency. The focus of this research is the physical elements of the building of the social house. The social houses of Kinikdog Hamlet are represented by ten houses as the research sample. The sample is selected based on the following criteria: 1) having significant design differences with other social houses and the differences must be able to be seen and measurable; 2) the houses should be permanent living places for the residents, and they must not halfway houses that are rarely occupied; and 3) the occupants are willing to be interviewed and allow the researcher to measure and make some documentation related to their houses.

The research data are collected using a mixedmethod, namely non-participant observation, semistructured in-depth interviews, and building measurements for primary data, and literature review for the secondary one.

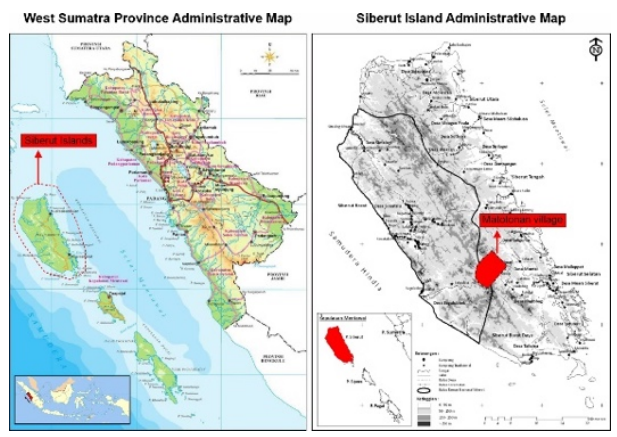

Figure 1 Location of Matotonan village

To observe the transformation in physical elements, a comparison technique is used between the initial design of the social houses and their current conditions. The results of the comparison are discussed and presented descriptively, and the results will be used for developing transformational patterns in the physical elements of the social houses in Kinikdog Hamlet, Mentawai Islands.

The data analysis is carried out in some stages, namely: Stage 1 - Analysis of physical elements in the initial design and sample of social houses using variables on the determinants of spatial encapsulation [7] and visual form characteristics (Ching, 1979); Stage 2 - Analysis of the factors causing the physical transformation, and; Stage 3 - Preparation of recommendations.

\section{Design Changes to Indigenous Community Settlement}

Transformation is a process that has been achieved and can also be defined as an adaptation [5]. In design and architecture fields, revealing transformation can be done by observing physical traces. [3] stated that buildings have the flexibility to respond to changes and react to the formation of the building itself and adapt to new types of transformation, so that later architectural aspect is not considered as static but can continuously grow and develop. According to [4], buildings and settlements will always transform because culture is always changing too. However, the transformations do not always occur simultaneously in all elements or arrangements. There are always elements that change and some that remain as they are (constancy).

According to Zeizel in [5] the transformation can be viewed by observing: 1) product use, which means observing the remnants of an activity 
sampling on the physical environment; 2) adaptation for use by observing changes made by users to the environment which can be in the form of addition or reduction of form or space; and 3) display of self and public message which consist of symbolic expressions using physical elements.

In general, there are three physical elements that make up the space: base/floor, boundary/wall, and cover/roof planes. Besides, there are determinants of the incomprehensibility of space that may influence the formation of space, namely: dimensions, form, configuration, surfaces, sides, and aperture [6]. In addition to determining the encapsulation of space, the physical elements can also be observed through the visual characteristics of its shape. According to Ching (1979), a form can be recognized because it has visual characteristics. Those characteristics are the main signs that indicate a form. They consist of shape, dimension, color, texture, position, orientation, and visual inertia.

Changes or transformations in architectural design are influenced by some factors. The design changes in social houses are closely connected to the factors that cause a settlement to change. [7] stated that the factors include political, social, cultural, technological, and economic aspects.

\section{RESULTS AND DISCUSSIONS}

In Kinikdog Hamlet, there are 90 social houses which are divided into 48 old social houses which were built in 2008 and 42 new ones in 2019. Based on the limitations of the research method, the author decides to observe only 10 of the 48 old social houses that meet the criteria. The following are the figures of 10 houses as the research sample and the data of their occupants and some necessary documentation.

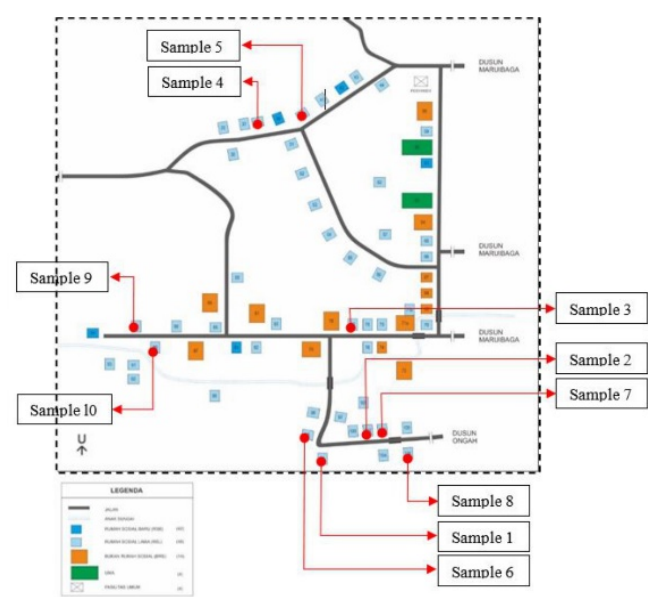

Figure 2 Location of social house sample

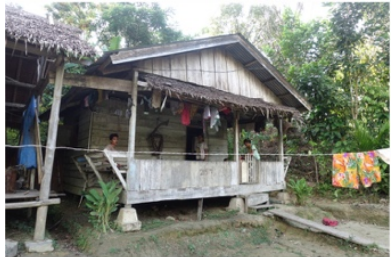

Sample 1

Owner: M. Rasyid

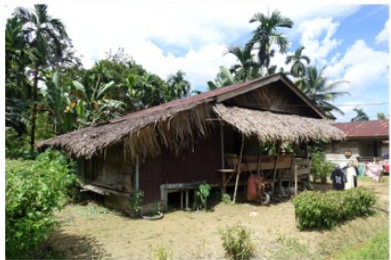

Sample 3

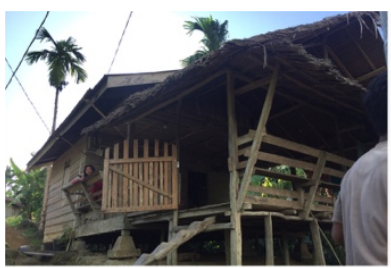

Sample 5

Owner: Teutumung

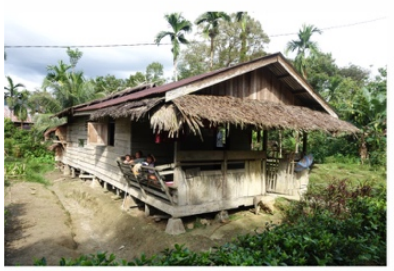

Sample 7

Owner: Anas Kleius

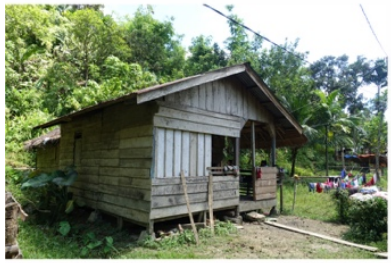

Sample 9

Owner: Zulfikas
Owner: Rifawanti

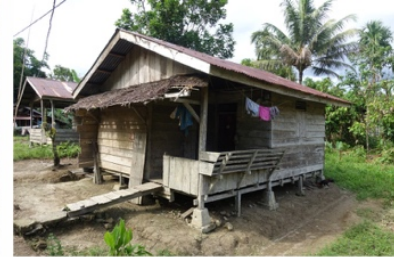

Sample 2

Owner: Sarip

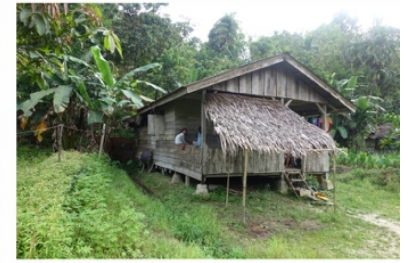

Sample 4

Owner: Te Em

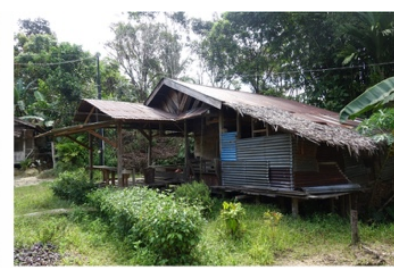

Sample 6

Owner: Ridwan

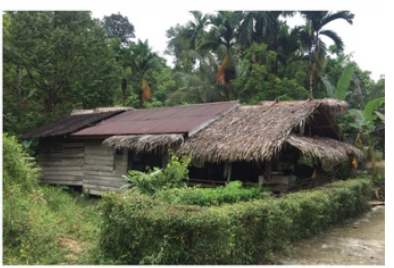

Sample 8

Owner: Jefri

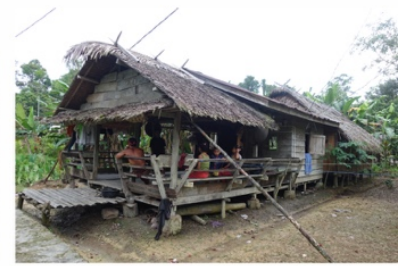

Sample 10

Owner: Pariaman
Figure 3 Photo of sample condition and homeowner

\subsection{Physical Elements Transformation of the Social Houses}

The transformational pattern of the social house design is made from the results of observations and analysis of the physical elements in each sample. 


\subsubsection{Form}

Figure 4 shows the entire sample of social houses. If we take a look at it carefully, the transformation occurs in some elements, including 1) addition of rooms during the initial building mass; 2) additional building mass; 3) addition of emergency or semi-permanent rooms; 4) addition of a walkway to the building facade; and 5) application of the Uma model in the social houses.

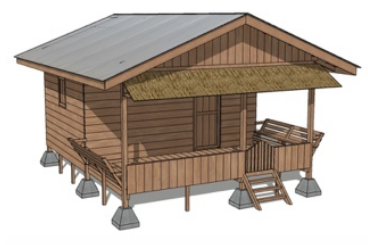

Sampel 1

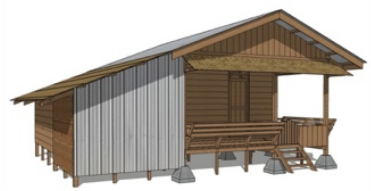

Sampel 3

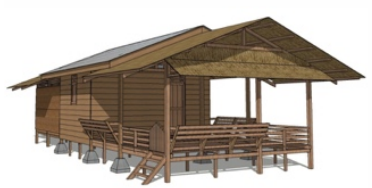

Sampel 5

Sampel 7

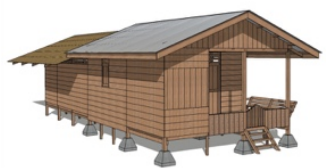

Sampel 9

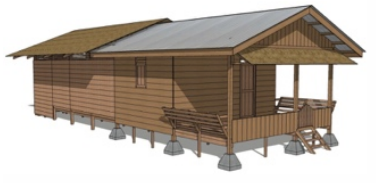

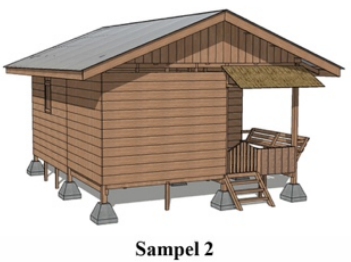

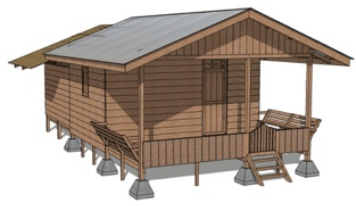

Sampel 4

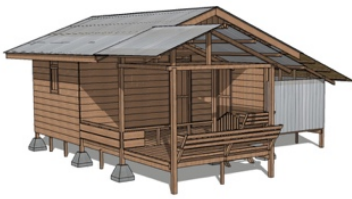

Sampel 6

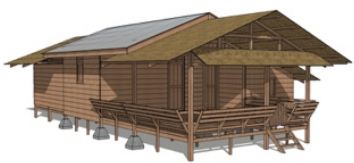

Sampel 8

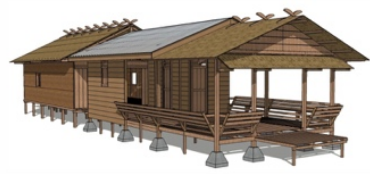

Sampel 10
Figure 4 Form of social house sample

The room addition during the initial building mass is found in samples 2 and 9. In percentage, this transformation happens in 2 out of 10 samples, or $20 \%$ of the sample social houses have been added with some rooms during the initial building mass. The position of the additional rooms in these two sampled houses is the same (in the front area of the right side of the building and serves as an additional bedroom). The additional building mass beyond the initial one is applied to 8 out of 10 samples.
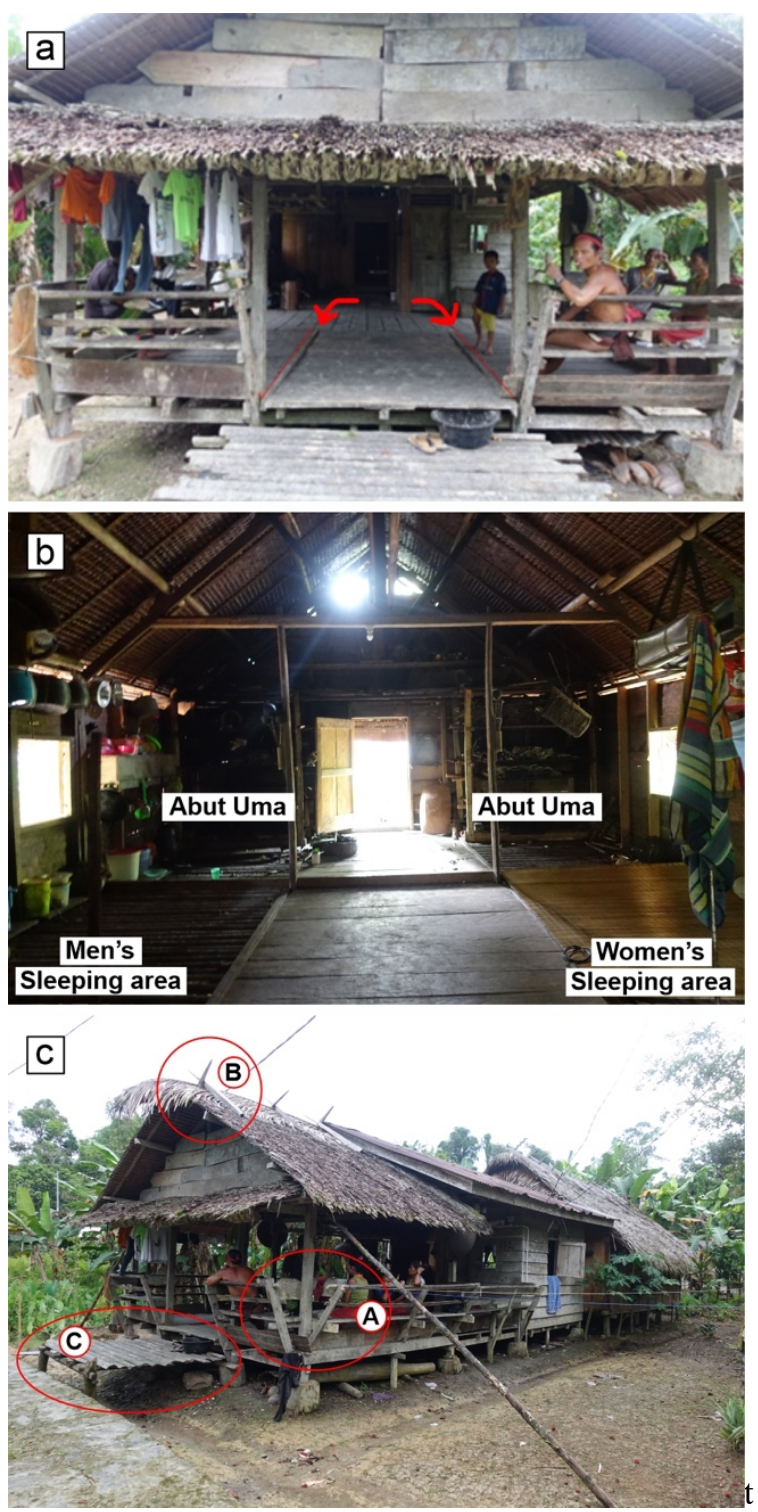

Figure 5 (a) division of 3 lanes of floor patterns in the front area of sample 10; (b) position of abut uma and bedroom in the back area of sample 10; (c) addition of physical elements resembling Mentawai Uma in sample 10

The transformational percentage is $80 \%$. The addition of building mass is carried out on all sides of the initial building such as the front side, backside, and right and left sides. The addition of emergency or semi-permanent rooms is only found in sample 1 . Out of ten samples, this point is only done in 1 out of 
10 samples, which means that only $10 \%$ of the entire sample experiencing such transformation. The emergency or semi-permanent room in sample 1 functions as a kitchen and is located at the back of the house.

The additional rooms with the Uma model are only applied in 1 of 10 samples (sample number 10). In this sample, the Uma model is applied in the floor pattern of the front and rear areas which are divided into three lanes (see Figure 5a). Also, the Uma model can be seen in the back area which has two furnaces (abut uma), and the bedroom which is divided into two parts (male and female sections) (see Figure 5b). In the front area, a bench model (tobbongan) is also applied with an L-pattern on both sides (indicated by the letter $\mathrm{A}$ in figure $5 \mathrm{c}$ ). Other forms that are similar to Uma are the wood at the top of the cross-shaped roof ridge (indicated by the letter B in Figure 5c) and the porch (gare) on the front and back of the house (indicated by the letter $\mathrm{C}$ in Figure 5c).

\subsubsection{Dimension}

Of the 10 samples of social house, 8 samples have experienced building dimensions transformation due to the addition of the building mass. They are

The narrowest building area is $30 \mathrm{~m}^{2}$ for the sample number 1 and 2, while the largest one is 97 $\mathrm{m}^{2}$ (sample number 10). The average building area is $59.3 \mathrm{~m}^{2}$. If the average value of the building area is used as a benchmark for determining the size of social houses, then from 10 samples, there are 5 samples of small social houses (lower than the average value) and 5 large samples (higher than the average value).

\subsubsection{Materials and Colors}

All sampled social houses are built from newly applied materials. The materials are thatched roof samples 3 to 10 . Samples 1 and 2 do not experience any dimensional transformation. From table 23 below, the dimensions of the social houses transform irregularly according to the additional building mass which is influenced by the number of rooms and the occupants' ability. However, if we take a look at the widest room, the front area is the largest one. Of the 10 samples, there are six whose largest room is the front area $(60 \%)$. The second largest one is the back room or kitchen in 3 samples $(30 \%)$. The last is the bedroom in 1 sample only or $10 \%$.

Table 1. House dimension

\begin{tabular}{|c|l|l|l|}
\hline Sample & Dimension $(\mathrm{m})$ & Area $\left(\mathrm{m}^{2}\right)$ & Widest Area \\
\hline 1 & $6 \times 5$ & 30 & Front area \\
\hline 2 & $6 \times 5$ & 30 & Bedroom \\
\hline 3 & $7,8 \times 6$ & 46,8 & Front area \\
\hline 4 & $9,5 \times 5$ & 47,5 & Kitchen \\
\hline 5 & $12,8 \times 5$ & 64 & Front area \\
\hline 6 & $8,4 \times 7,5$ & 52,5 & Front area \\
\hline 7 & $14 \times 8,25$ & 81,8 & Back area \\
\hline 8 & $13 \times 8$ & 84 & Front area \\
\hline 9 & $12 \times 5$ & 60 & Front area \\
\hline 10 & $17,95 \times 5,85$ & 97 & Back area \\
\hline
\end{tabular}

and bark. They enrich the housing color scheme even though it is still in the same color tone (natural brown and gray from concrete and aluminum zinc). If we look at table 2 below in the new materials column, $100 \%$ of the sampled social houses use thatched roofs, while $40 \%$ of the samples use thatched roofs and bark. Both materials are used in Uma and other community houses long before the existence of the social house. Those materials are still available and can be taken freely from nature although today they are not as much as they used to be.

Table 2. House materials and colors

\begin{tabular}{|c|c|c|c|}
\hline Sample & Material & Color & New Material \\
\hline 1 & & & Thatched roof \\
\hline
\end{tabular}




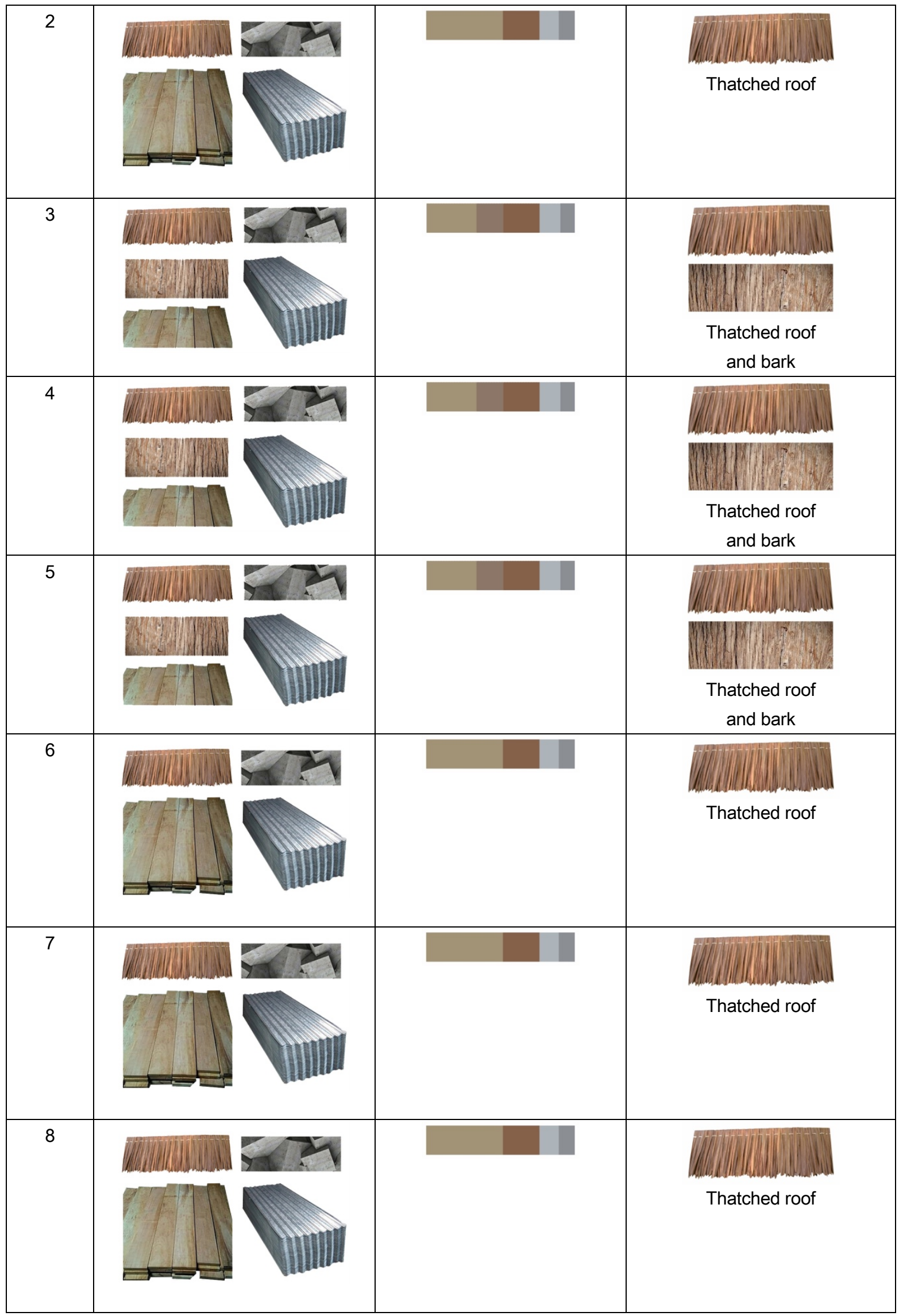




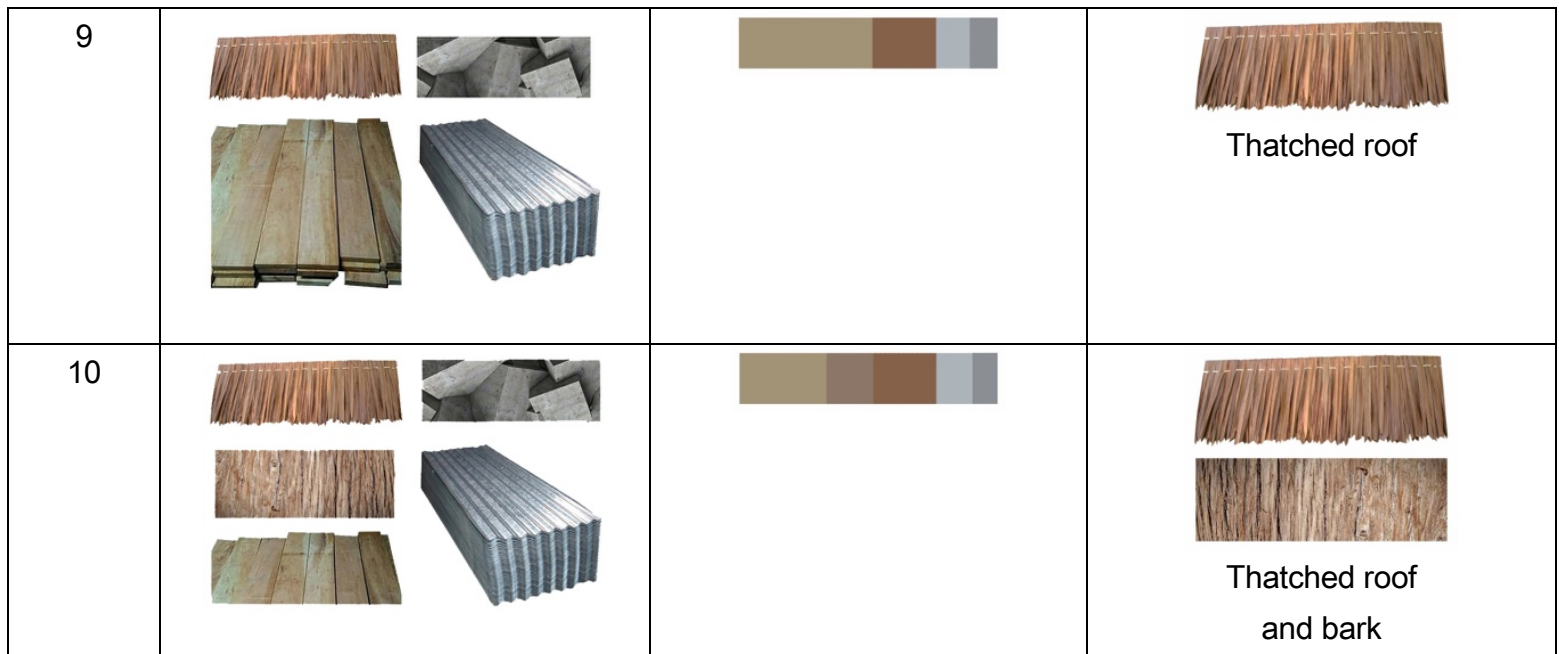

\subsubsection{Orientation}

At the beginning of the construction process, the social houses were oriented to face the road. However in reality, not all social houses in Kinikdog Hamlet face the road precisely. Of the 10 samples, two samples are not orientated facing the road, but one of them is then transformed in such ways that it is finally road oriented. Figure 6 below shows the orientation, cardinal directions, and pictures of each sampled social house.

From the figure, we can see $90 \%$ of the building's facade is directed to hamlet road. One sample that does not face the road is sample 4 .

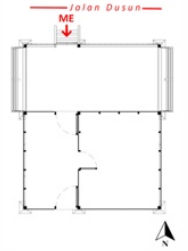

Sample 1
Facing the road (north)

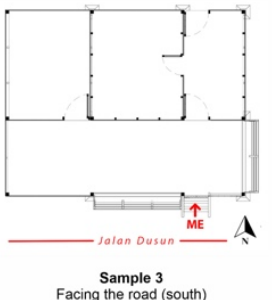

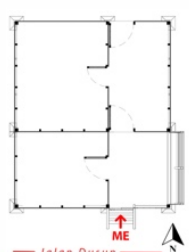

Sample 2
Facing the road (south)

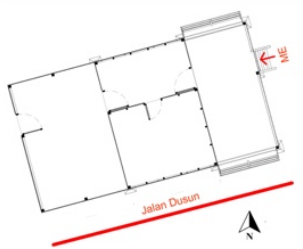

Sample 4

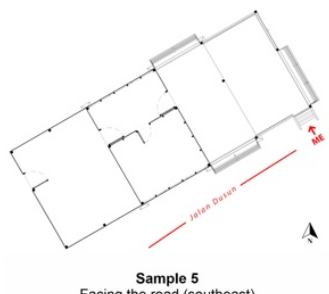

Sample 5
Facing the road (southeast)
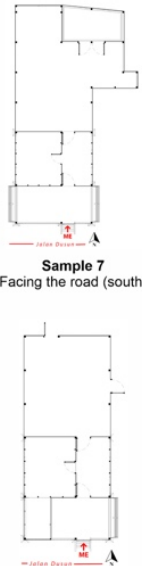

Sample 9
Facing the road (south)
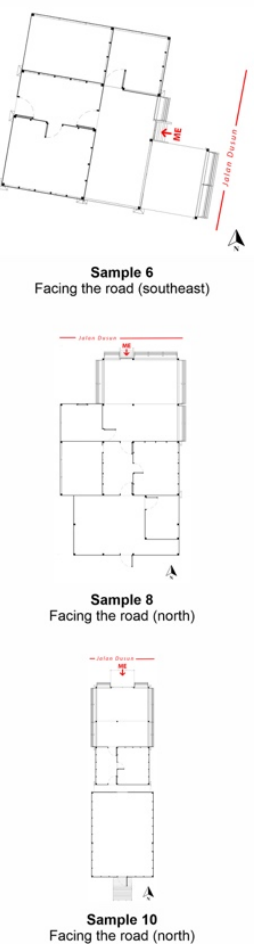

Figure 6 House orientation

The hamlet road is on the right side of the house. Based on the cardinal directions, most of the buildings face south and north. There are 4 samples of building facades facing south, 3 samples facing north, 2 samples facing southeast, and 1 sample facing northeast.

\subsubsection{House Aperture}

There were initially some apertures made in the social houses; three for doors, and two for windows. From several samples, these apertures are maintained 
even though some do not function optimally due to the addition of building mass on the side of the window wall. Also, the residents have added few apertures by themselves. Figure 7 below shows the number of apertures, additional apertures, and pictures of the apertures in each sample.

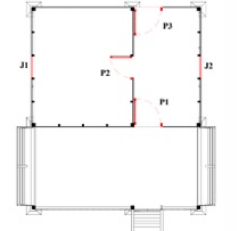

Sample 1

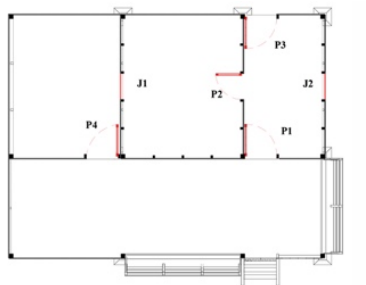

Sample 3
Add 1 door

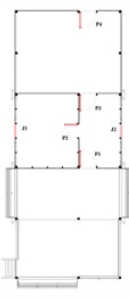

Sample 5
Add 1 door

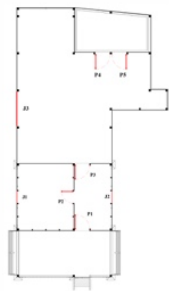

Sample 7
Add 2 doors and 1 window

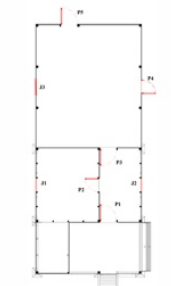

Sample 9
Add 2 doors and 1 window

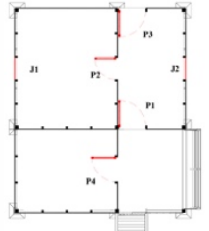

Sample 2
Add 1 door

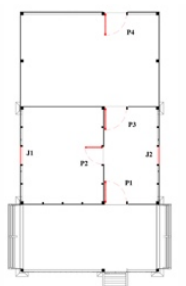

Sample 4
Add 1 door

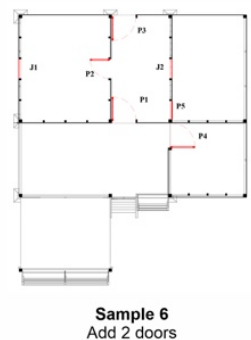

Add 2 doors

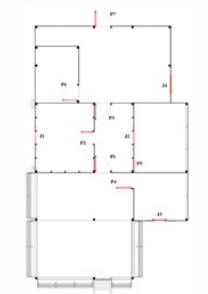

Sample 8
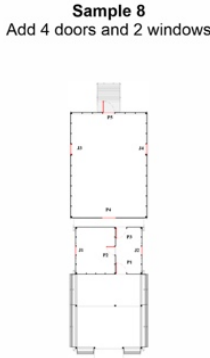

Sample 10
Add 2 doors and 2 wind
Figure 7 House aperture

If we observe the table above, 9 out of 10 samples of social houses have experienced additional apertures. One sample that does not have any additional apertures is sample 1 which does not experience any additional space or building mass. The doors are made in all samples which serve as access to the additional rooms. This explains that the addition of doors in the social houses is caused by the addition of space or building mass. The addition of windows is quite minimal. From 10 samples, there are 8 rooms in 6 samples of social houses that do not have windows. There are only bedrooms and kitchens to be made. This is following the opinion of some residents that windows are not a necessary priority. The most important thing for them is that there must be a room that can accommodate main life activities such as cooking and taking a rest. From the table above, the highest number of additional apertures is in sample 8 with four additional doors and two windows, while the least one is in sample 1 with no additional apertures. The average number of additional apertures in 10 samples is 2.2 .

\subsection{Transformational Factors}

The factors causing the transformation can be identified from the results of interviews with some residents. Meanwhile, the factors are then analyzed based on the findings from [7]. The following is an explanation related to the factors triggering the transformation in physical elements in the Kinikdog Hamlet social houses.

\subsubsection{Form}

Transformation in form occurs due to the additions of rooms, building mass, walkways, and the application of the Uma model. Based on the interviews with the residents, they re-construct their houses to support their daily activities such as a kitchen for cooking, sleeping room, and front areas as the living rooms, because the original social houses design provided by the government do not accommodate their actual needs.

The addition of space and building mass is done according to the occupants' capacity, social position in the family, and skills in carrying out houses development. The capacity in question is not about financial, but the ability to collect and process raw materials from the forest and carry out additional construction. Meanwhile, the addition of the porch and the application of the Uma model to the social houses is mainly caused by the residents' skills residents in carrying out the construction, references from traditional houses in Kinikdog Hamlet before the existence of the social houses, and a desire to 
bring out the original identity of the Mentawai islands in the social houses. This discussion explains that the transformations that occur in the social house are influenced by some factors; social, cultural, and technological aspects.

\subsubsection{Dimension}

The social house dimensions have transformed in terms of size and area. It is commonly caused by the addition of the building mass. From the results of interviews with the residents, the building mass is transformed based on the occupants' expectations. The greater the need, the stronger the motive to increase the building mass, but not all residents can re-construct the building mass. The ability to transform the building mass is influenced by the ability to collect materials and process them well and carry out construction as well as social status in the middle of community and family. The added dimensions of the building mass are not influenced by certain cultural values, but rather by the ability and availability of land. This discussion explains that changes in the dimensions of the social house are influenced by technological factors and social factors.

\subsubsection{Materials and Colors}

According to local and some experts, the two new materials used to build the social houses are freely available in nature and do not require many costs. Also, they can support Mentawaian identity because they were previously used in every local traditional building before the existence of the social houses from the government. This explains that materials and colors changes in social houses are influenced by economic and cultural factors.

\subsubsection{Orientation}

The social houses are mostly oriented facing the hamlet road, it has been agreed by local government, village officials, and community representatives from the beginning of the designing and building process. The main reason is that the houses should look harmonious among each other and they can be easily accessed from anywhere. The building orientation, according to the cardinal directions, is dominated by the north and south, which is in line with the sun's circulation. However, some houses face west and east because the land is located on the side of the road that lies from north to south. This shows that the house orientation is greatly influenced by the location of the land on the hamlet road. The discussion above explains that the orientation to the social houses has not changed because there are no standard rules. Thus, there is no change factor as stated by [7] in this aspect.

\subsubsection{House Aperture}

House apertures are commonly spent by the residents to make the doors because the doors are the main access towards additional rooms. There are more doors made because there are also some additional rooms or building mass. The window is not a priority according to them, so not all the rooms in the sampled houses have windows. People do not mind if the rooms are quite dark because they are used to living without electricity and most activities are carried out during the day. According to some people, their house windows are relatively similar to the previous houses, and their shapes are influenced by the occupants craftsmanship skills and the availability of tools and materials.

From the explanation above, the increasing number of apertures and their shapes which remain the same from the beginning are affected by cultural and technological factors. It can be concluded that transformation in the physical elements of the social houses is triggered by economic, social, cultural, and technological aspects. Of these factors, the most influential are cultural and technological ones.

\subsection{Recommendations for the House Design}

Recommendations for social house design are prepared based on the analysis results of the physical elements of the social houses. These recommendations are prepared for optimizing the development of social housing in the future.

The house shape/form can be optimized by adding a porch on the front of the building and a stove/fireplace with the Uma model, increasing the roof height, and maintaining building shape to remain the same and in line with the cultural values of the Mentawai people such as a gable roof and benches (tobbongan) in the front area. The social houses dimension can be maximized according to government regulation $\left(36 \mathrm{~m}^{2}\right)$.

To anticipate the development and maintenance that use local materials, the roof should be made more tilted and higher, using first-grade wood that has been available around the hamlet, so that the building can last longer. There should be also good cooperation among community members in material fulfillment. Long-term programs must also include 
trees and sago planting to provide building materials when the social houses are needed to be wellmaintained and developed.

The building orientation can be optimized by facing the houses to the north and south during the initial construction process. The apertures can be optimized by increasing the size of the windows or making additional windows on the dividing wall between the bedroom and the front area.

\section{CONCLUSIONS}

From some discussions presented in the previous sections, we can conclude that the social houses in Kinikdog Hamlet, Matotonan Village, South Siberut District, Mentawai Islands Regency are quite flexible as explained by Kronenburg (2017). Since the initial construction process, the social houses of Kinikdog Hamlet have undergone a significant transformation. Some elements have changed and some have been fixed and cannot be transformed into other functions. The transformation does not occur simultaneously in all elements as stated by Rapoport (1969). Using physical traces on the houses' physical elements, some following conclusions can be drawn.

1. The space configuration of the social houses has changed due to the existence of new rooms. There are some additional rooms such as the front area, bedroom, kitchen, and bathroom. The additional rooms commonly function as the kitchen, followed by an additional front area and additional bedrooms/sleeping rooms.

2. Most of the deepest rooms in the social houses shown by the j-graph graph have not transformed at all, such as bedrooms (both the main bedroom and the additional one). The value of the j-graph in the social houses that have undergone development has increased by one point from the initial value of the j-graph during the house construction and design stage (from 3 to 4 ).

3. The highest connectivity value in social houses that have undergone development is 4, but in general, they get a score of 3 which is shown by the connectivity value graph. The values increase one to two points from initial connectivity values during the social houses' initial design stage. Generally, the rooms that have the highest connectivity values (most connections) are the front areas and living rooms. It is just the same as the initial design of the social houses.

4. The rooms that have the highest integration values in the social houses that have been re- developed are the living rooms and the front areas with a percentage of $60 \%$ and $40 \%$, respectively. Meanwhile, the rooms with the lowest integration values are the areas outside the house and bedrooms with a percentage of $60 \%$ for each. The rooms with the highest and lowest integration values are the same as the initial design and construction stage of the houses.

The physical elements transformation of the social houses is greatly affected by several factors, namely economic, social, cultural, and technological aspects. Of these factors, the most influential ones are culture and technology. The social houses are developed along with local wisdom and understandings that are passed down from generation to generation and are represented by the buildings where they used to live before the existence of the social houses. In addition, social houses are also a representation of the local people's skills and abilities in carrying out local development. The people's ability to utilize construction technology will affect the shape/forms, tidiness, and efficiency of the construction process. Economic factors are not the main change factor because all materials are taken from their surrounding environment and are done independently according to their respective constructive skills.

\section{ACKNOWLEDGMENTS}

The authors would like to thank Mr. Hariadi Kerei, Mr. Jonas Salemurat and his family, Mr. Rinaldi Sagoilok and his family, and Mr. Rusman Wahyu and his family, who have accepted and helped the author a lot during the research stages in Mentawai. The authors also would like to thank Dr. Maskota Delvi for the assistance given to support the success of this research.

\section{REFERENCES}

[1] Lindstrom, M. Brand sense: Sensory Secrets Between Behind The Stuff We Buy. New York: Free Press, 2005.

[2] Keputusan Menteri Permukiman dan Prasarana Wilayah Nomor: 403/KPTS/M/2002 Tentang Pedoman Teknis Pembangunan Rumah Sederhana Sehat (Rs SEHAT). Lampiran V: Pedoman Teknis Rumah Sederhana Sehat Rumah Kayu Panggung, 2002.

[3] Kronenburg, R. Flexible: Architecture that Responds to Change. London: Laurence King Publishing, 2007. 
[4] Rapoport, A. House Form and Culture. University of Winconsin, Milwaukee, 1969.

[5] Sari, I. K. Perubahan Karakter Arsitektur Permukiman Kampung Beting Kota Pontianak Kalimantan Barat. Jurnal Langkau Betang, Vol. 1 No. 2014.

[6] Surasetja, R. I. Fungsi, Ruang, Bentuk, dan Ekspresi dalam Arsitektur. Hand-out Mata Kuliah Pengantar Arsitektur Program Studi Arsitektur FPTK UPI, 2007.

[7] Yunus, H. S. Struktur dan Tata Ruang Kota. Yogyakarta: Pustaka Bel, 2000. 